Giovanni Cocozza, Dr. iur.

University of Naples Federico II, Italy

\title{
SOCIAL REPORT OF PUBLIC ADMINISTRATIONS AND PRINCIPLE OF TRANSPARENCY
}

\section{VALSTS PĀRVALDES IESTĀŽU SOCIĀLAIS ZIN̦OJUMS UN PĀRREDZAMĪBAS PRINCIPS}

\begin{abstract}
Kopsavilkums
Šajā rakstā aplūkota sociālā ziņojuma un tā instrumentu nozīme ceḷā uz valsts pārvaldes iestāžu darbības caurskatāmību, labu administratīvo darbỉbu un korupcijas novēršanu, uzlabojot privāto un valsts pārvaldes iestāžu sadarbïbas veidus. Itālijas tiesību sistēmā pilnīga pārredzamības principa ieviešana tiek sekmēta, izmantojot virkni reformu, kuras veiktas pēdējo gadu laikā. To mērkis ir panākt maksimālu pārredzamības principa paplašināšanu atbilstoši vispārējām vajadzībām, kuras tiek uztvertas arī Eiropas līmenī. Šajā kontekstā raksta mērkis ir ierosināt īpašas regulas ieviešanu, lai veicinātu izmainas attiecībās starp privāto un valsts pārvaldi un padarītu administratīvos pasākumus efektīvākus, jo īpaši, ja skartas jutīgas intereses, piemēram, saistībā ar vides jautājumiem. Attīstības ceḷš parāda arī tendenci izmantot dažus biznesa pasaulei piederīgus jēdzienus, kuri noder, lai paraudzītos uz attiecībām ar valsts pārvaldi no citas perspektīvas. Jāuzsver īpašs sociālā ziṇojuma regulējums, it īpaši vietējās pašvaldībās, kur tam nepieciešamas tiešākas attiecības starp valsts pārvaldi un pilsoñiem. Tas ir arī līdzeklis, lai veicinātu kultūras maiṇu, kas spētu palīdzēt izveidot plānošanas un kontroles tîklu, kurā līdzdarbotos sabiedrība un kura mērḳis būtu apmierināt pilsoṇu vajadzības, cieši sasaistot zināšanas, vienprātību un savstarpēju uzticēšanos.
\end{abstract}

Atslēgvārdi: valsts pārvalde, pārredzamības princips, sociālais ziņojums, pilsoniskās tiesibas

\section{Summary}

This paper looks at the role of the social report and its instruments for achieving the transparency in the activities of public administrations, good administrative performance, as well as for countering corruption, enhancing forms of cooperation between private and public administrations. The full realization of transparency is developed, in the Italian legal system, through a series of reforms in recent years aimed at achieving maximum expansion of the principle, in line with general need also perceived at European level. In this context, the paper aims to propose introduction of a specific regulation to contribute to a change in the relationship between private and public administration and make administrative action more effective, especially when there are sensitive interests involved, for example, those regarding environmental issues. The evolutionary path also shows a trend to use some concepts belonging to the business world, useful to obtain a change as to the observation perspective of the relationship with the public administration. In the overall picture, it should be emphasized that a specific regulation of the social report would be needed, especially within local authorities, where it requires a more immediate relationship between public administration and citizens. It is also an instrument to promote a 'cultural' change, capable of pursuing the objective of creating a planning and control network, with public action aimed at meeting the needs of citizens in a way where knowledge, consensus and trust are closely linked.

Keywords: public administration, principle of transparency, social report, citizens' rights 


\section{Introduction}

Transparency in the activities of the public administration, which has always been sought after, is still central in the present debate. It is encircled by an important conceptual consideration with a dynamic production of regulations, increasingly aimed at achieving a 'total know-how', inspired by the Freedom of Information Act $(\text { FOIA })^{1}$, which originated in the U.S., and later was extended to other legal systems.

Transparency has been recognized, indeed, as an essential aspect of a system capable of offering the most extensive guarantees to its members. It is an instrument to counteract all forms of corruption in the public administration and, more generally, to redress the inefficiency and malfunctioning of the public administrations ${ }^{2}$. This should also be achieved through cooperation between private and public administration.

It is worth to recall an old expression of a noted Italian politician, Filippo Turati, which sums up the need very well: "Where a higher, public interest does not impose a temporary secrecy, the house of the Administration is to be made of glass"3. Thus, transparency is presented as an absolute value to be achieved, overcoming any obstacle.

This shows the complexity of implementing this proposition, which is why, even today, despite the significant progress made, we have not yet achieved a fully satisfactory set-up ${ }^{4}$ and why every instrument must be used to achieve it.

As a part of the full realisation of the transparency principle, the theme of 'Corporate Social Responsibility' becomes increasingly essential also in public law, especially in crucial and delicate public interests (for example, those regarding environmental issues), with liabilities for the choices made by the management.

The paper focuses on the perspective of using the 'social report' as a further step capable of achieving a 'total know-how' that has inspired the legislator in recent years. It represents an instrument that can play an increasingly significant role in the activities of public administrations.

\section{Evolution of the principle of transparency in Italy}

The first consideration focusing on the issue of transparency is its adequate definition. Many elements lead us to consider it as a systemic principle and, as such, immanent in the same decisions of the Italian Constitution as an essential feature of the

1 Freedom of Information Act (FOIA) is a law that protects freedom of information and the right of access to administrative documents.

2 Mattarella B. G. La prevenzione della corruzione in Italia. Giornale di diritto amministrativo, No. 2, 2013, p. 123; Patroni Griffi F. Gli strumenti di prevenzione nel contrasto alla corruzione. No. 14/2014. Available at: www.federalismi.it [last viewed July 31,2019]; Patroni Griff F. Battere la corruzione: una sfida impossibile? No. 20/2015. Available at: www.federalismi.it [last viewed July 31,2019].

3 Turati F. Atti del Parlamento italiano, Camera dei deputati, sessioni 1904-1908, 17 giugno 1908, p. 22962.

4 D'Alterio E. Pubbliche amministrazioni in crisi ai tempi della trasparenza. Giornale di diritto amministrativo, 2018, no. 4, p. 511. 
public administration for achieving the principles of good performance and impartiality as set out in Article 97 of the Constitution.

Hence, it may be said that transparency is "a structural character of public power which must be achieved using all the instruments provided for by the regulations to this end"s.

The path that led to the present structure allows us to grasp, although in brief form, some stages that have characterized the evolution of the legislation and that clearly indicate a gradual process of formation ${ }^{6}$.

The first important step was the approval of Law No. 241 of $1990^{7}$ (General Law on Administrative Procedure), which marked the end of "administrative secrecy", which has influenced administrative activity over decades and was a clear manifestation of the immense distance between administration and citizens, and the relationship between these two parties was characterized by a position of supremacy of the administration.

However, only in 2009 (Article 11 of Legislative Decree No 150/2009 ${ }^{8}$ ) transparency came to mean 'total accessibility' (no longer limited) to 'information' (heretofore just administrative documents) relating to every aspect of the action and organisation of administrations (even if the matters concerned performance management), in order to promote forms of 'widespread control', in compliance with the principles of good performance and impartiality.

At this point, a further step ${ }^{9}$ is trying to achieve a model of transparency, through open data and open government, able to promote the active participation of citizens in administrative decisions, "on the assumption of an open administration that makes the information in its possession available to the community". This model, recalling the US one based on the Freedom of Information Act (FOIA), declines the new general principle of administrative transparency as total transparency (total disclosure) based on the obligation to publish documents, information and data regarding the most relevant aspects of the organization and the functioning of public administrations on websites. In order to ensure respecting these obligations the 'civic' right of access is provided, allowing all citizens to request publication of the documents ${ }^{10}$.

Lastly, it may be said that, in recent years ${ }^{11}$, transparency has expande ${ }^{12}$ even further when it was stated that its purpose is "to protect citizens' rights" and "to promote the participation of the parties concerned in administrative activity". In addition, the

Pajno A. Il principio di trasparenza alla luce delle norme anticorruzione. Giustizia civile, No. 2, 2015, p. 226.

6 Amodio A. Dall'accesso documentale all'accesso civico generalizzato: i nuovi paradigmi della trasparenza dellazione amministrativa. No. 5/201. Available at: www.giustamm.it [last viewed July 31, 2019].

Available at: www.normattiva.it [last viewed July 31, 2019].

8 Available at: www.normattiva.it [last viewed July 31, 2019].

9 Legislative Decree No. 33/2013. Available at: www.normattiva.it.

10 Cudia C. Appunti su trasparenza amministrativa e diritto alla conoscibilità. No. 12/2016. Available at: www.giustamm.it [last viewed July 31, 2019].

11 Legislative Decree No. 97/2016. Available at: www.normattiva.it [last viewed July 31, 2019].

12 Ponti B. Nuova trasparenza amministrativa e libertà di accesso alle informazioni. Maggioli, 2016. 
right of 'generalized' civic access is provided for, which citizens can use to know about the various types of administrative documents ${ }^{13}$.

\section{The influence of the European regulations on the concept of transparency}

The above considerations signal that expanding the concept of transparency is a result of progressive evolution of the Italian legal system with an important junction in the 2009 reform, when, as stated above, the principle of administrative transparency underwent a real 'genetic mutation ${ }^{14}$. This significant difference of approach is the basis for further development, whereby transparency becomes a tool to contribute "to the creation of an open administration serving the citizen", which is a "condition for ensuring individual and collective freedoms and civil, political and social rights", as well as an expression of the "right to good administration" (Article 1(2) of Legislative Decree No. $33 / 2013^{15}$ ) laid down in Article 41 of the Charter of Fundamental Rights of the European Union.

At this point, one can see in the evolution of the principle of transparency the influence of a general trend that goes beyond the scope of national legislation and finds consistency also through the impulse of the European Union ${ }^{16}$, where this principle is directly referred to in Article 15 of the Treaty on the Functioning of the European Union, which states: "In order to promote good governance and ensure the participation of civil society, the Union's institutions, bodies, offices and agencies shall conduct their work as openly as possible" and that "Each institution, body, office or agency shall ensure that its proceedings are transparent".

It should be noted that the enhancement of transparency in the European system involves several levels ${ }^{17}$. Just think of what the European Union did in 1998 with regard

13 D'Urgolo G. Trasparenza e prevenzione della corruzione nella P.A.: la recente introduzione del "Freedom Act of Information" (FOIA) nell'ordinamento italiano. No. 3/2017. Available at: www.giustamm.it [last viewed July 31,2019]; Galetta D.-U. Accesso civico e trasparenza della Pubblica Amministrazione alla luce delle (previste) modifiche alle disposizioni del D. Lgs. No. 33/2013. Available at: www.federalismi.it, [last viewed July 31,2019 ]., No. 5/2016; Villamena S. Il c.d. FOIA (o accesso civico 2016) ed il suo coordinamento con istituti consimili. Available at: www.federalismi.it [last viewed July 31,2019], No. 23/2016; Carloni E. Il nuovo diritto di accesso generalizzato e la persistente centralità degli obblighi di pubblicazione. Diritto amministrativo, 2016, No. 4, p. 579.

14 Patroni Griffi F. La trasparenza della pubblica amministrazione tra accessibilità totale e riservatezza. Available at: www.federalismi.it, No. 8/2013 [last viewed July 31, 2019].

15 Available at: www.normattiva.it [last viewed July 31, 2019].

16 Kranenborg H., Voermans W. Access to Information in the European Union. A Comparative Analysis of EC and Member State Legislation. Groningen, 2005; Massera A. I principi generali dell'azione amministrativa tra ordinamento nazionale e ordinamento comunitario. Diritto amministrativo, 2005, No. 4, p. 707; Locchi G. Il principio di trasparenza in Europa nei suoi risvolti in termini di Governance amministrativa e di comunicazione istituzionale dell'Unione, 2011. Available at: www.amministrazioneincammino.it [last viewed July 31, 2019].

17 Savino M. The right to open public administrations in Europe: emerging legal standards. Available at: http://www.epsa2011.eu/files/Themes_2011/OECD\%20Administrative\%20Transparency\% 201010.pdf [last viewed July 31, 2019]. 
to environmental information. Taking up the resolutions of the Rio Conference on Environment and Development, the first article of the Aarhus Convention states:

In order to contribute to the protection of the right of every person of present and future generations to live in an environment adequate to his or her health and wellbeing, each Party shall guarantee the rights of access to information, public participation in decision-making, and access to justice in environmental matters in accordance with the provisions of this Convention.

The Convention has also been implemented by Italy in $2005,{ }^{18}$ allowing everyone to obtain the information held by public administrations regarding the environment, without indicating the reasons for the request.

\section{A possible role of social report?}

The framework outlined above provides useful elements for questioning the possibility to extend some tools actually used in the business world to public administrations.

It is necessary, however, to overcome the resistance that prevents an adequate interrelationship between public and private law, for a safer guarantee to citizens and a full implementation of the principle of transparency.

Thus, the proposal of a specific regulation finds its justification, since it allows empowering the public administration to make its activities transparent, independently from the request of citizens to obtain knowledge of such activities.

It can be said that the social report is a tool through which the administration can promote 'responsible participation' of citizens, disclosing the social effects arising from management decision making. Such a role can serve as a basis for change in the relationship between private individuals and public administration, in a perspective of greater responsibility on behalf of the latter for the results achieved at economic, ethical, social and environmental levels, capable of directing its action towards the primary needs of citizens.

Therefore, this greater transparency enhances cooperation and provides a way of reducing the gap between social reality and public activity, which over the years has also been powered by citizens' conviction that public administration is a limiting factor in economic development due to the rigid impositions applied to individuals and companies.

The proposal of this paper to make the social report mandatory, through new forms of information and participation of citizens in administrative activity can make them not only users of the service provided, but also active interlocutors who can influence the performance and, therefore, the quality level of services. In other words, a process where knowledge, consent and trust are tightly linked.

On the other hand, there is a trend in the Italian legislation, pursued by the reforms introduced in the final decade of the last century, which is inspired by the so-called "New Public Management" (NPM), typical of the Anglo-Saxon culture, aimed at improving the quality and efficiency of public services.

18 Legislative Decree No. 195/2005. Available at: www.normattiva.it [last viewed July 31, 2019]. 
The process is developed through use of management models of business world and equates the relationship between public administration and citizen with the one between companies and customers. This enhances the level of efficiency in the provision of public services and the quality perceived by citizens in their role as customers, as well as customer satisfaction. As a consequence, the citizen becomes the milestone for the change in public administration, able, as a recipient, to evaluate the service provided: through his satisfaction, he can legitimize the public organization and its work; through his participation, he contributes to the modernization process of the administrative structure.

\section{Social report to local authorities and use of private business models}

The suggestion of this paper for a greater assimilation between models of public law and private law, also trough a legislative reform capable of making mandatory some tools, not provided until today to public administrations, is further recognized if one looks at what happens to the local authority level, where the relationship between public administration and citizens is more immediate ${ }^{19}$. Therefore, we can see that the local authorities increasingly present themselves as 'regulators' of a complex system of relations (with businesses, citizens, associations, other bodies), where diverse interests need to be reconciled in order to achieve a common synergy capable of allowing an adequate development of the community.

The notion of 'public value' appears as an element that indicates the entity's capacity to be a boosting factor for development, where the social report becomes, from this point of view, an instrument for measuring such value, as it satisfies the need for dialogue, openness and comparison that comes from citizens and other entities in the territory. Thus, the specific willingness of the institution to establish a cooperative path with citizens and community is measured.

The success of extending some concepts, which belong to the business world, to local authorities. For instance, the concept of 'Corporate social responsibility' aiming at "representing and promoting the development of the local community". This is a commitment for citizens, businesses, other public institutions and employees. Therefore, the concept of 'Corporate social responsibility' extended to public administrations consolidates the link between institutions and local communities, in contrast with the logic of sovereignty linked to the exercise of authoritative functions. The so-called "Accountability" provides a response to the need for each organization with roles of responsibility to communicate to its interlocutors the decisions taken in relation to the treatment of use of environmental and economic resources, as well as the results achieved. This represents a commitment for citizens, businesses, other public institutions and employees.

19 Hinna L. Il bilancio sociale nelle amministrazioni pubbliche. Processi, strumenti, strutture e valenze. Milano: Franco Angeli, 2004. 
What has been just said finds confirmation at the European Union level, in the European Commission's Communication of 2002 concerning "Corporate Social Responsibility: a contribution of companies to sustainable development":

Public administrations, including the Commission, need to practice CSR principles in their own management and with their own 'stakeholders'.

The Commission has decided to take a more integrated and systematic approach to the management of social and environmental matters within its administration. [...].

The Commission intends to:

- integrate further social and environmental priorities within its management, including its own public procurement;

- assess its social and environmental performance by publishing a social and environmental report by 2004;

- launch an awareness raising campaign towards the Commission's agents in 2003.

The Commission invites public administrations at national, regional and local level to also examine their practices with a view to integrating social and environmental considerations.

With reference to the Italian legislation, interesting documents should be reported.

So, the directive of the Minister for Public Social Accountability in the Public Administrations (2005) states that the use of social reporting techniques is of "particular relevance" and has a "specific potential".

It is noted that the social accountability can be a "response to the lack of comprehensibility of public reporting systems in terms of action transparency and regarding the results of public administrations, explicit aims, policies and strategies, performance measurement and communication". And the social report, from this point of view, becomes the main instrument "to give an account of the administration's activities". It is defined as the "document, to be issued on a regular basis, in which the administration reports, for the benefit of all its private and public interlocutors, the choices made, the activities carried out and the services provided, giving an account of the resources used for this purpose and describing its decision-making and operational processes".

Clearly there is a great potential for the sensitive areas in which this instrument might be used. For example, the particular relevance of the environmental report.

In this context, an important step was the City and Local Environmental Accounting and Reporting (CLEAR). This is the first European environmental accounting project applied to local authorities that envisages the creation and approval of 'green budgets' by a significant sample of Italian municipalities and provinces (18 Italian local authorities). The final objective is to produce a report on the state of the environment that allows a correct evaluation of the planned and implemented interventions.

In this way, social reporting systems were already developed in many communities. 


\section{Conclusions}

The considerations presented herein generate an inevitable question.

Despite of the actual tendency towards an evolution of the principle of transparency in the Italian and European context, where the transparency has become increasingly important and despite the widespread recourse to private law categories by public law, can the current normative framework that aspires to make public administrations' decisions more transparent be still considered sufficient?

The recognized role of social reporting forms is, in particular, to activate the social control', upon which the achievement of 'good public management performance' may depend in a significant way. For this reason, the issue of social responsibility of local authorities deserves increased attention.

However, care should be taken that the effects of 'social control' should not be limited to a perspective of merely control, since they must necessarily involve further aspects as well, creating a complete circuit of planning and control from a 'social' point of view, where the role of stakeholder consultation appears essential.

Within an administration it seems appropriate to achieve a 'cultural' climate that pursues full awareness of the citizens, so as to overcome any antagonism between them and the institutions.

By way of conclusion, the proposal of extending the social report to public administrations can be particularly fruitful because of the relevant link with the principle of transparency. Those are the instruments that can help to achieve the transition from a limited vision of interventions only aimed at preventing wrongdoings of the administration to a broader perspective as a basis for creating a good administration, with a public action focused on meeting the needs of citizens and attaining the economic and civil progress of society. A result to be achieved with enhancement of the cooperative chain in which the public sector can benefit from the participation of private sector for a better performance of its functions.

\section{BIBLIOGRAPHY}

1. Amodio A. Dall'accesso documentale all'accesso civico generalizzato: i nuovi paradigmi della trasparenza dell'azione amministrativa. Available at: www.giustamm.it, No. 5/2018 [last viewed July 31,2019$]$.

2. Carloni E. Il nuovo diritto di accesso generalizzato e la persistente centralità degli obblighi di pubblicazione. Diritto amministrativo [Administrative Law], No. 4, 2016, p. 579.

3. Cudia C. Appunti su trasparenza amministrativa e diritto alla conoscibilità. Available at: www.giustamm.it, No. 12/2016.

4. D’Alterio E. Pubbliche amministrazioni in crisi ai tempi della trasparenza. Giornale di diritto amministrativo [Journal of Administrative Law], No. 4, 2018, p. 511.

5. D’Urgolo G. Trasparenza e prevenzione della corruzione nella P.A.: la recente introduzione del "Freedom Act of Information" (FOIA) nell'ordinamento italiano. Available at: www.giustamm.it, No. 3/2017 [last viewed July 31, 2019].

6. Donati D. Il principio di trasparenza in Costituzione. In: La trasparenza amministrativa. Milano, Giuffrè, 2008, p. 83. 
7. Hinna L. Il bilancio sociale nelle amministrazioni pubbliche. Processi, strumenti, strutture e valenze. Milano: Franco Angeli, 2004.

8. Galetta D.-U. Accesso civico e trasparenza della Pubblica Amministrazione alla luce delle (previste) modifiche alle disposizioni del D. Lgs. n. 33/2013. Available at: www.federalismi.it, No. 5/2016 [last viewed July 31, 2019].

9. Gardini G. Il paradosso della trasparenza in Italia: dell'arte di rendere oscure le cose semplici. No. 1/2017. Available at: www.federalismi.it [last viewed July 31, 2019].

10. Kranenborg H., Voermans W. Access to Information in the European Union. A Comparative Analysis of EC and Member State Legislation. Groningen, 2005.

11. Locchi G. Il principio di trasparenza in Europa nei suoi risvolti in termini di Governance amministrativa e di comunicazione istituzionale dell'Unione, 2011. Available at: www.amministrazioneincammino.it [last viewed July 31, 2019].

12. Massera A. I principi generali dell'azione amministrativa tra ordinamento nazionale e ordinamento comunitario. Diritto amministrativo [Administrative Law], No. 4, 2005, p. 707.

13. Mattarella B. G. La prevenzione della corruzione in Italia. Giornale di diritto amministrativo [Journal of Administrative Law], No. 2, 2013, No. 2, p. 123.

14. Patroni Griffi F. Gli strumenti di prevenzione nel contrasto alla corruzione. No. 14/2014. Available at: www.federalismi.it, [last viewed July 31, 2019].

15. Patroni Griffi F. Battere la corruzione: una sfida impossibile? No. 20/2015. Available at: www.federalismi.it [last viewed July 31, 2019].

16. Patroni Griffi F. La trasparenza della pubblica amministrazione tra accessibilità totale e riservatezza. No. 8/2013. Available at: www.federalismi.it [last viewed July 31, 2019].

17. Pajno A. Il principio di trasparenza alla luce delle norme anticorruzione. Giustizia civile [Civil Justice], No. 2, 2015, p. 226.

18. Ponti B. Nuova trasparenza amministrativa e libertà di accesso alle informazioni. Maggioli, 2016.

19. Savino M. The right to open public administrations in Europe: emerging legal standards. Available at: http://www.epsa2011.eu/files/Themes_2011/OECD\%20Administrative\%20Transparency\%201010.pdf [last viewed July 31, 2019].

20. Villamena S. Il c.d. FOIA (o accesso civico 2016) ed il suo coordinamento con istituti consimili. No. 23/2016. Available at: www.federalismi.it [last viewed July 31, 2019]. 